\title{
Review
}

\section{Christopher Yeomans. The Expansion of Autonomy. Hegel's Pluralistic Philosophy of Action. New York: Oxford University Press, 2015. ISBN 978-0-19-939454-8 (hbk). Pp. 228. £45.90.}

Christopher Yeomans's new book is devoted to explaining what kind of moral psychology and philosophy of action guide Hegel's effort to grant objectivity to Kant's concept of a self-determining will and even to demonstrate its actualization in particular forms of citizenship. The challenge is to illuminate how Hegel's concept of freedom - abstractly understood as 'being at home with oneself in the other', or recognizing oneself in an other-entails that our moral duty is to meet the obligations of a particular social role (the farmer, the craftsman, the industrial producer, the public servant, and so on), while recognizing that these social roles are both chosen by agents and socially defined. According to Yeomans, 'more than anyone else in the tradition, Hegel tries to work out in detail the way in which individual agency is compatible with deep ties and influences that come with being a social and embodied subject' (82).

The book is divided into three parts. The first offers a reconstruction of Hegel's critical appraisal of Kant's concept of autonomy in the context of his reception of the Doctrine of Virtue in the Metaphysics of Morals. There Kant tries to specify the duties of beings like us not naturally inclined to act according to the moral law: initially, the duty of developing their very capacity to act morally. One of the aims of Yeomans's book is to show that Hegel's philosophy, in this domain, develops immanently from the Kantian approach. For this reason, Yeomans's argument is built upon Kant's understanding of virtue as the individualization of duty (15).

Yeomans argues that Hegel's concept of self-determination (Selbstbestimmung) is constituted by three different sub-projects: a generic affective identification with our own existence and life (self-appropriation), the specification of the content of this life in preferences, plans, interests, etc., that we can take as our own (specification of content), and the effective realization by ourselves of the ends that this specification determines (effectiveness) $(2 \mathrm{f}$.). Yeomans considers Kant's Doctrine of Virtue to already address the first two, and Fichte's work on ethics, continuing the investigations of the Metaphysics of Morals, to emphasize the importance of the third. But Hegel viscerally 


\section{Review}

disapproves of his predecessors' idea that moral duty contradicts—and therefore must subdue-natural inclinations toward self-interest insofar as they adulterate genuine moral motivation. Hegel also strenuously resists the claim that our practical faith in God's role as judge and rewarder will reconnect what Transcendental Idealism has axiomatically set apart. For Hegel, on these premises the essential expressive ingredient of the concept of self-determination cannot find satisfaction, as Yeomans argues (80).

The first part culminates in a chapter that lays out the alternative moral psychology that underlies Hegel's non-empiricist, and indeed expressivist, way of expanding and particularizing the concept of self-determination. The key concepts of Hegel's moral psychology are, for Yeomans, talents and interests, understood not as dispositions, but as distinctive modes of activity that are objective (public) and constitutive of the agent (73). Talents help to anchor actions in their circumstances, since they are themselves circumstantial and modes of access to other circumstances. Interests determine the way in which human beings make these circumstances their own and give them the shape of their own self. Interests represent the element of agency that the agent cannot dissociate herself from, according to Yeomans, since we cannot have interests that we do not identify with (81).

The second part of the book is divided into three chapters, each of which examines one of the three sub-projects that, according to Yeomans, constitute the moments or aspects of Hegel's concept of self-determination. The main thread of this part is a novel interpretation of the 'Morality' chapter in Hegel's Philosophy of Right. Yeomans thinks that the rights of subjectivity and objectivity that 'Morality' successively addresses define three forms of accountability or even agency, inseparable but distinguishable, that correspond to those expressive projects. But Yeomans does not only provide a novel analysis. Additionally, he tries to show how the different forms of life characteristic of what Hegel (as was usual in his time) calls 'estates' (Stände) — that of peasantry, craftsmen, industrial producers, soldiers, public officials, scholars, and merchants-amount to differently structured embodiments of the projects of self-appropriation, specification of content and effectiveness. At the same time, he observes ineradicable tensions and unavoidable compromises between those projects. The result of Yeomans's substantial interpretative work is an overview of Hegel's understanding of the multiple forms of self-determining agency realized in and through distinct social roles, each embodying a different combination of those aspects of self-expression and deserving for that reason equal respect and recognition. As he sees it, it is this multiplicity of adequate embodiments that Hegel's philosophy of action is intended to capture $(90,127)$.

The Expansion of Autonomy's concluding chapter constitutes a separate part. In this chapter, Yeomans tries to show that such a plural social objectification of 


\section{Review}

individual self-determination conceptually satisfies four desiderata arising from the shortcomings perceived by Hegel in Kant's Doctrine of Virtue. The first desideratum is to oppose the Kantian view of morality and freedom as a 'fight' of reason against nature not with a simplistic Hobbesian compatibilist conception of free agency, but with an ethical analysis of the principled particularization of paradigmatic moral ends (such as beneficence) in material ends (like hospitality in the case of farmers) through the development of specific moral attitudes toward other agents in the context of the forms of life of the different estates. A second desideratum, namely, to overcome the mechanistic threat to agency and particularly to a robust sense of selfhood in action, is met by the concept of 'character' (Yeomans's translation of Gesinnung, see 114), insofar as Hegel sees character as the result of a dynamic interaction of talents and interests through which the self can recognize more and more her own shape. Hegel's third achievement is said to consist in a correct appraisal of some non-empiricist resources for the explanation of action that seem to suit an expressivist view, such as circumstances, character, common projects and interests. Finally, Yeomans shows, by means of concrete examples, that Hegel's philosophy of action provides objective criteria for distinguishing deception and hypocrisy from integrity in the moral behaviour of members of different estates, thus succeeding where Kant and Fichte's 'empty formalism' seemed to fail.

There are many things to agree with in Yeomans's argument. Firstly, he is surely right in emphasizing the importance of the individualization of duty and the problem of formalism for Hegel's ethical theory. It is also true, it seems to me, that Hegel's concept of self-determination is fundamentally expressivist and that, as a consequence, the central ethical concept is for him 'character' or mindedness (Gesinnung) and that a conceptualization of mundane bootstrapping toward morality and rationality is to be found at the core of his moral psychology (89 f.). I am also willing to subscribe to the interpretation of his philosophy of action as teleological and non-empiricist.

From the point of view of the exegesis of Hegel's work, perhaps the most controversial aspect of Yeomans's book is the way in which it connects purpose, intention and the good-the three topics of 'Morality'- to the expressive projects of self-appropriation, specification of content, and effectiveness. It is also questionable whether the preservation of a moral point of view in ethical life (Sittlichkeit) should be understood in terms of the particularization of those projects. It would be possible to argue that the moral point of view, analysed by Hegel in three different underdetermined kinds of accountability, is rather a one-sided approach to action that must be sublated into properly institutionalized ethical perspectives. More than aspects of self-determination, purpose, intention and the good may signal limited understandings of accountability that progressively correct each other and are jointly unsatisfactory. 


\section{Review}

Equally controversial, in my view, is Yeomans's interpretation of subjectivity and objectivity in $\$ \int 25-26$ of the Philosophy of Right as ingredients to be combined or coordinated in a general ethical project.

Even more striking is that Yeomans does not consider the specifically political role of the estates, a role that in my view is essential to Hegel's philosophy of ethical life. As Hegel gives so much importance to the political realization of freedom, one might have expected a discussion of the rationality and moral or ethical value of the political order. To say that the book explores just 'one line' of the expansion of autonomy (2) and that the political role of the members of the states is 'complicated by Hegel's unique philosophy of law' (7) seems a shallow justification for ignoring this central element in Hegel's argumentation.

The bracketing of this aspect goes hand in hand with a significant disregard for the specifically modern articulation of ethical life. In fact, The Expansion of Autonomy does not properly address the rationality of the modern family, modern civil society and modern political representation, despite its claim that the individual project of self-determination is to be advanced by taking part in objective institutions. Yeomans certainly appears to conceive his investigation as a complement, rather than an alternative, to the discussion of such rationality. But it remains for me unclear how a psychological understanding of the project of self-determination could be combined with a non-psychological approach (such as, for instance, Robert Pippin's). It seems difficult to reconcile Yeomans's view of talent as the objective side of the idea (in Hegel's technical sense of the term) (195) with the more common view of institutions as freedom-realizers.

A different question is whether Yeomans succeeds in reaching his own limited purpose: to present the diverse characters of Hegel's social world (the farmer, the craftsman, etc.) as authentic moral figures, in which the ideal of self-determination and particularly of self-expression is adequately attained. A proper evaluation of this achievement cannot be undertaken here; but interestingly, Yeomans himself seems only moderately satisfied in this regard: he admits that 'in all fairness...though Hegel has gone further in the direction of the expansion into the particular than Kant or Fichte, on his own terms even the system reconstructed here...cannot be considered the finished article of such expansion' (196).

Nevertheless, Yeomans's work excels in elaborating scarcely explored connections between Hegel's moral philosophy and social theory and Kant's and Fichte's accounts of virtue, in its detailed analysis of the estates from a moral point of view, and in defending a new understanding of the so-called 'overcoming' of morality in the substance of ethical life. The Expansion of Autonomy will not only be of interest to Hegel scholars and historians of philosophy. As Yeomans persuasively shows, the debates between Kantians and 


\section{Review}

Hegelians about the way in which particular social roles might actualize the abstract moral ideal of self-realization remain fundamental for contemporary ethics and contemporary philosophy of action.

\section{Edgar Maraguat \\ University of Valencia, Spain \\ edgar.maraguat@uv.es}

